\title{
Globalization, fiscal policy and free competition: The impact in EU
}

\author{
Maria do Rosário Anjos ${ }^{1,2, *}$ \\ ${ }^{1}$ ULP - Lusófona University of Porto, Faculty of Law and Political Sciences, R. de Augusto Rosa 24, \\ 4000-098 Porto, Portugal \\ ${ }_{2}^{2}$ IJP - Portucalense Institute for legal research, Rua Dr. António Bernardino de Almeida, 541, Porto, \\ Portugal
}

\begin{abstract}
.
Research background: Globalization has profoundly changed the rules of play in the international economy. A new world order, new challenges and new difficulties have arisen as well new strategies to avoid the consequences of global free competition. Fiscal policy is a crucial tool in new global competition model, in special for regions with a high level of economic integration, as EU. In this context tax harmonization is extremely important to prevent distortions of competition in European market.

Purpose of the article: Study the political and institutional constraints of the tax harmonization and disclosure a small part of the initial results of a investigation project about "tax competition in EU". Understand if and how lack of tax harmonization between the member states is one of the causes of inequity between them, in special the Euro zone countries.

Methods: Comparative study about income tax's in Euro zone countries and the relation to PIB, as well the deductive method to analyse the results we find and some reference studies on the subject.

Findings \& Value added: The goal is answer to the follow questions: what are the political and institutional limitations to tax harmonization in EU? Why there are no further progress in the field of tax harmonization? Can EU and Euro zone survive face a globalization challenge with the present fiscal disloyal competition between member states? What future for EU in a globalization era? Findings show that tax harmonization never was considered as a priority in EU, and maybe never will, what is a weakness in a globalization world.
\end{abstract}

Keywords: globalization; free competition; tax competition in EU; new world order; regulation in $E U$

JEL Classification: $K 34 ; H 2 ; F 6$

\footnotetext{
* Corresponding author: rosario.anjos@ulp.pt
} 


\section{Introduction}

Globalization has profoundly changed the rules of play in the international economy. A new world order, new challenges and new difficulties have arisen as well new strategies to avoid the consequences of global free competition. Fiscal policy is a crucial tool in new global competition model, in special for regions with a high level of economic integration, as EU. In this context tax harmonization is extremely important to prevent distortions of competition in European market [1].

Creating and developing the EU fiscal system is not only an economic, but also an important political process. Generally, the fiscal system rests on the institutions and instruments necessary for the implementation of fiscal policy on a certain area. Creating institutional fiscal infrastructure at a supranational level of the EU is rather complex and limited due to globalization fiscal trends, but also due to political complexity of the integration of traditionally independent EU member countries [2] The problem is that in economies with high level of integration the budgetary and fiscal discipline is crucial for the success of the process [3]. Without fiscal harmonization we cannot guarantee the right conditions for free and fair competition between member states [4].

We can say that EU have done everything to achieve their goals in economic plan but did all this without a real tax harmonization in euro zone. This was and is one of the biggest mistake in the European construction process, because the lack of an appropriate European fiscal policy and tax harmonization had as result the worsening of budgetary indiscipline, the increase in public debts of some Member States and the use of the tax system as an instrument of unfair competition between member countries [5].

In other words, what Articles 101 and 102 of the TFUE prohibit the different tax laws allow. The useful effect desired by the application of the European competition law can be easily circumvented, among others, by the taxes or tax benefits that each country provides to foreign investors who receive in its Countries in the expectation of increasing GDP [6]. Despite the European Commission's efforts globalization has introduced new challenges that have led to more flexible interpretations of the rules of European competition law [7]. According Odete Oliveira «the last few decades, if not a century, globalization has been one of the key processes and the main feature of the development of the world economy, and it is here that all the fundamental changes in the economic policies of the leading world powers are significantly reflected. The current stage of globalization is characterized by such a policy of several countries, which leads to the destruction of established economic ties, increased protectionism, sanctions wars, increased economic instability, and a general slowdown in GDP growth rates» [8]

Actually, there is an increasing critical opinion about the impasse of the globalization process and the advent of the de-globalization of the world economy [9]. For these authors, nowadays, there is an obvious slowdown in globalization processes [10].

The distribution of the benefits of globalization between countries depends largely on tax competition between different countries. So why does the EU do nothing to stop tax competition between its Member States and achieve more fiscal harmonisation and greater economic and social cohesion in the euro area? Is tax competition harmful or beneficial to Member States? Who wins and who loses in this game?

This issue is not new [11]. In 1999, Milne \& Banstead published an interesting study on this subject and concluded that fiscal harmonization, while indispensable to the cohesion of the European project, would be very difficult because of this game [12] No member state would truly want to lose the possibility of a tax system to attract investors and greater wealth for their countries, exposed by the Treaty to free competition that can be theoretically beneficial but which economic operators do not want 
All we know that the largest companies today relate differently to their foreign direct investment, since the digital economy allows them to operate on a global scale and act on foreign markets with virtual presence there, so the need for foreign assets to do business abroad is significantly reduced. They can choose their head office based on the best tax performance (lower tax rates or better tax benefits) without relocation costs.

In a context of virtual economy, the impact of globalization makes states use the fiscal system as a way to face the economic crisis [13]. Globalization affects economic growth and social development [14]. According to the KOF Globalization Index, which measures the economic, social and political dimensions of globalization, economic inequality has increased even more with the process of globalization [15]. In this context EU needs to take more effective measures to strengthen the internal cohesion of the Euro zone, considering the possibility of non-PDO growth in the coming decades [15-16]. Nevertheless, we believe that the EU should take some measures to preserve the level of well-being achieved and avoid disaggregation. Further fiscal harmonization and budgetary discipline is indispensable to maintain the European project, weakened by BREXIT and all the economic difficulties of the last decade.

\section{The impact of fiscal policy in free competition European Union}

The main goal of the European integration was creating common (single) market based on free competition between all member countries to do the next steps: an European Union and a monetary zone with "Euro" as a common currency [17].

In this context the guarantee of free and loyal competition between member states is a condition "sine qua non» to realize the purposes of EU. The existing system of common market didn't have only a basic economic dimension but also the political one. Since the beginning, the Rome Treaty tried to guarantee free and loyal competition between member states. This was and still is the most important condition to an effective European economic integration, the process of this integration can also be seen as a way to a stronger political integration. As Šimović we think that the "conditions relevant for creating then an economic union did not refer to a political union and it is exactly this segment which today may be the biggest obstacle to a stronger and faster political EU integration.» [18]

In an era of globalization, the union between Member States is particularly important. But the truth is that we have come with the "Brexit novel" only disagreement and disorientation in the EU.

The fiscal harmonization is impossible without political union. Meanwhile, member states use the tax system to promote their own interests, either to obtain more foreign investment or to achieve greater GDP growth by capturing companies from other member states to host their businesses in the countries with better taxation [19].

According Šimović «the system of public finances, was always on the border-line between the political and economic aspect of any country and/or integration. In the case of the EU, the fiscal system is a reflection for the level of demarcation between the market integration and a stronger political union».

Indeed, the EU tax system plays an important role in the integration of EU markets and allows for the necessary cohesion to maintain the current level of EU economic and political integration. The last years were very difficult for all but in UE the consequences are still unknown. Income inequality could have serious consequences for the future of the EU. But the last decade has been a kind of "perfect storm": the 2008, 2011 crisis, the refugee crisis, Brexit, and now the pandemic situation of COVID 19 with serious consequences for the recovery of economies.

It is, therefore, obvious that clear and aggressive tax competition within the EU undermines free competition and the single market. Lower taxes mean cheaper goods and 
services at more competitive prices and that means a distortion on free and healthy competition within the EU. We can say that EU challenge in the next years is: run to political union or stop, wait and die? We say: run!

It has always been in the most acute times of crisis that Europe has made history and has taken the most important steps towards a better future. The big challenge is reverse the current situation to take a step forward to a political union and correct the mistakes of the past, in particular, the constitution of an economic and monetary union without fiscal harmonization.

\section{The "Fiscal Gap" between EU member States and how it affects the free competition}

The structure of the European fiscal system comes down to the EU budget as the only instrument for implementing the fiscal policy from the central supra-national EU level [20] The rest of the fiscal system can be seen as a set of different rules and arrangements through which the member countries harmonize and coordinate other segments of fiscal policy. This primary refers to "harmonization of taxation and coordination of stabilization fiscal (budget) policies through Stability and Growth Pact (SGP) and Maastricht convergence criteria" [21].

The impact of taxation on free competition is indisputable. The poorest UE countries need so much to captivate foreign investment that justifies all tax benefits and lower tax rates adopted. But interestingly, it is noted that in many of these countries (ex. Portugal) high rates of income taxes feed a budgetary indiscipline between 2006-2011 that has condemned the country's prosperity. Economic cycles and crisis do condition governments in such a way that the governance is not determined by ideology but by the circumstances in which each government comes to power [22].

All the authors cited agree with the idea that high income taxation has a negative impact on economic growth and countries development. Budgetary discipline and good allocation of resources by governments of the different member states are also essential to the economic and social success [23].

So, if we guarantee a free competition market but allow differences on income taxation the economic integration will not be real. Tax harmonization is the only solution to a real free competition in EU market.

The existence of two very different cultures in the EU, one based on a more popular and interventionist governance model and the other more restrained and disciplined, has resulted in an economic and social gap between two distinct groups of countries. The best results are presented by the second group: richer, more disciplined but also with lower tax rates. It is obvious that the older countries of the Eurozone and some other EU countries that have opted for lower taxes in recent years are able to attract more foreign investment and are more attractive for the European companies, that change their fiscal residence to these countries with a more "friendly taxation" (ex. Netherlands; Luxembourg or Ireland). This situation is a serious distortion on free competition between UE member States.

There are a "fiscal gap" between EU member States that means a seriously problem of disloyal competition in market. Lower taxes means lower prices and an advantage in the internal market and in international transactions as so.

The existence of different groups of countries within the EU, with different levels of economic and social growth and growth, is not a new reality. In 1985, Bressand talked about a world economy and an European Community on three speed e "une Europe au trois vitesses vers une economie mondiale au trois vitesses" [17]. What worries us is that more than 30 years later we see that the EU remains unequal and no cohesion in sight. Between the texts of the Treaties and reality there is such a difference that it makes us think 
that EU has followed the wrong way and is at serious risk of disaggregation. The new generations do not understand or accept an unequal and aimless EU. BREXIT was a first start, but perhaps it is not the only one. So, the only way to keep the European project alive is to do the next step: fiscal policy harmonization in order to prepare the political union.

It is clear the difficulty of harmonizing tax rates and rules for determining the subject of tax in an environment such as the EU, which is composed of several countries, with various levels of economic development and with different types of tax system. The tax rate greatly influences a country's GDP (St. When a country has a high tax burden, it is a sign that it is heavily regulated and this is one of the main reasons for the low economy growth. Some European Union countries have higher GDP's and higher tax to support the welfare state, as Nordics. In this case the higher GDP's are able to support the higher taxes, so there are no problem.

The EU has no direct responsibility for tax collection or the setting of its fees. Each national government decides the taxes that taxpayers must pay, as well as how revenues are spent. However, the EU oversees national tax provisions in some areas, notably those relating to European policies affecting businesses and consumers, in order to ensure the free movement of goods, services and capital within the European single market; to ensure that companies in one country do not enjoy an unfair advantage over their competitors from other countries; to ensure that taxes do not discriminate against consumers, workers or businesses in other EU countries. The single market allows free trade in goods and services across the EU. To make life easier for businesses and avoid distortions of competition, EU countries have agreed to harmonize the applicable rules on the taxation of goods and services. Some sectors benefit from specific agreements, such as value added tax (VAT) or taxes on energy products and electricity, tobacco, and alcohol. In addition, the EU works with Member States to coordinate their economic policies and corporate income taxes, in order to ensure their fairness and effectiveness and ensure that they are growth friendly [25].

This is a key issue to ensure greater clarity about taxes due by people moving to another EU country or by companies investing in another EU country. This coordination helps to prevent tax evasion and avoidance but is to soft [26].

Is that enough? We don't think so. We need to go further in the taxation of businesses and household within the EU in order to ensure that the tax rates or tax benefits granted by certain member states do not result in serious distortions of free competition within the EU. The key is to go further in tax harmonization.

\section{Results: findings and discussion}

As we mentioned, this study is based on a comparative analysis of income taxes in euro zone countries and the relationship with GDP. We did a literary review and analysed the results we found.

We present the summary exposition of the results as follow:

1. About differences in the tax burden in EU countries in the period from 2004 to 2018 we concluded that the countries with the smallest tax burden is Romania $(28.1 \%)$ and Bulgaria (28.7\%). The highest rates are from the Nordic countries, Denmark (47.7\%), Sweden (46.2\%) and Belgium (45.5\%). Almost twice the lowest.

2. The relation to GDP is obvious: Romania and Bulgaria have the lowest GDP's and the Nordic countries have the highest GDP's.

3. In the same period Netherlands, Luxembourg and Ireland (in part) had higher GDP's level but with low income taxes and a system of fiscal benefits that put the tax near « 0 » for some cases of foreign investors; Germany and France had some difficulties to maintain the GDP's performance and the income taxes are high, especially, in France. 
4. The worst performance was in the southern countries: Portugal, Italy, Greece and Spain, with GDP falling and income taxes rising.

5. Other countries such as Poland, Hungary, Slovakia, Slovenia, Croatia, and the Czech Republic have shown low but positive growth in their GDP's by practicing low tax rates and with strong tax incentives and tax exemptions for foreign investors, which includes EU countries.

In conclusion, the goal of this study is answer to some questions we mentioned in introduction. So, the answers we find are as follow:

1. What are the political and institutional limitations to tax harmonisation in the EU? The economic asymmetries still existing between member states, with traditions very different from the point of view of budgetary discipline and control of public expenditure. Like the dominant ideologies within the EU, two separate guidelines can be clearly distinguished: a group of countries of south Europe with governance focus in a strong and expensive public administration and the other, more liberal and disciplined and with greater control over public spending.

2. Why there are no further progress in the field of tax harmonization? Because the different member States do not want to give up their fiscal sovereignty and have been delay for decades relevant decisions on tax harmonization. Thus, tax competition between them is quite real and acts as a vehicle for distortion of free competition with a clear advantage for countries with greater budgetary discipline and lower taxes or more tax benefits.

3. Can EU and Euro zone survive face a globalization challenge with the present fiscal disloyal competition between member states? That's the million-dollar question. We believe that EMU (euro area) will only survive with effective fiscal harmonisation and greater economic and political integration. Otherwise, economic and social divergences between poor and richer countries will destroy economic and social cohesion. This is a crucial issue for the success and continuity of the European project. Without more union of social cohesion the European project could collapse.

4. What future for $\mathbf{E} \mathbf{U}$ in a globalization era? The EU must strengthen internal ties between its members to address trade competition with the rest of the world and maintain its strategic influence. Successive recent crises and the new pandemic reality have reinforced the need for collaboration between countries at global level, particularly on sensitive issues such as health, science, knowledge and international trade.

On the economic level, we are seeing some signs of combating globalization and introducing new barriers between peoples. In a time of change and uncertainty like the one we live in there are signs of a setback in the process of globalization of economies and rebirth of dangerous nationalisms. In this context the future of the EU and its euro area will require well-structured measures to move forward with further economic and social cohesion and for that we need more fiscal harmonization between member States.

\section{Conclusion}

Findings show that tax harmonization never was considered as a priority in EU, and maybe never will, what is a weakness in a globalization world. There is clear tax competition between the European member States which somehow replaces the old protectionist barriers that the Treaty has abolished. Member States maintain their fiscal sovereignty, which promotes such competition, specially, by setting corporate income tax rates and granting tax benefits. This latter instrument allows to grant tax benefits to multinational companies in return for the investment made.

Over the past decade, the use by EU member states of fiscal instruments, as a way to compete with each other and capture foreign investment, has become too aggressive. 
Tax competition between member countries also extends to personal income tax, as the excessive tax burden on households in some Member States provides an incentive to move and establish other member states with better wages and lower taxes.

It was perhaps a reaction to the effects of the globalization process, but it is strong risk to the European integration project. We hope that so soon as possible EU can go further in the process of integration to an effective economic union looking on a future political union that preserve the best values of the old Europe.

\section{References:}

1. Anjos, M. R. (2019). Free Competition and Fiscal Policy in European Union. In D. Dukic, T. Studzieniecki \& J. Grzinic (Eds.), Economic and Social Development 49th International Scientific Conference on Economic and Social Development Development - "Building Resilient Society" (pp. 254-262). Varazdin: Varazdin Development and Entrepreneurship Agency.

2. Haan, J., Sturm, J. (1994). The Political and Institutional Constraints of Fiscal Policy in the European Union. Public Choice Review, 80(1-2), 157-172.

3. Alesina, A., Perotti, R. (1996). Fiscal Discipline and the Budget Process. American Economic Review, 86(2), 401-407.

4. Montagnier, G. (1995). Harmonisation Fiscale Communautaire. Revue Européenne, 5, 25-34.

5. Collins, Hutchins (1988). Articles 101 and 102 of the EEC Treaty: completing the internal market. Porto: Centro de Estudos Europeus da Universidade Católica Portuguesa.

6. Jacobs, J. P. A. M., Samad, S., Sturm, J. E., van Norden, S. (2020). Can GDP measurement be further improved? Data revision and reconciliation. Journal of business \& economic statistics.

7. Anjos, M. R., Fionda, R. (2020). Prohibition of restrictive Competition Agreements in the European Union: Analyzing the 'EXPEDIA' Case. In E. Pinto da Costa, M. do Rosario Anjos \& M. Przygoda (Eds.), Economic and Social Development 52nd International Scientific Conference on Economic and Social Development Development (pp 505-515). Varazdin: Varazdin Development and Entrepreneurship Agency.

8. Oliveira, M. O. (2020) Sustainable Tax Systems. In E. Pinto da Costa, M. do Rosario Anjos \& M. Przygoda (Eds.), Economic and Social Development 52nd International Scientific Conference on Economic and Social Development Development (pp 223229). Varazdin: Varazdin Development and Entrepreneurship Agency.

9. Efremov, V. S., Vladimirova, S. I. (2019). Globalization of the World Economy: Features of the Current Stage. In 40th International Scientific Conference on Economic and Social Development (pp. 27-36). Buenos Aires.

10. Dreher, A. (2006). Does Globalization Affect Growth? Evidence from a new Index of Globalization. Applied Economics, 38(10), 1091-1110.

11. Easson, A. J. (1993). Taxation in European Comunity. London: The Athlone Press.

12. Milnes, B. B. (1999). Tax Competition: Harmful or Beneficial?. Intertax, 27(3), 86-88.

13. Barry, F. (2001). Fiscal Policy in EMU. In: E. Pentecost, A. van Poeck (Eds.), European Monetary. Integration. Aldershot: Edward Elgar. 
14. Haan, J., Sturm, J. (2017). Finance and income inequality: A review and new evidence. European journal of political economy, 50, 171-195.

15. Gygli, S., Haelg, F., Potrafke, N., Sturm, J. (2019). The KOF Globalisation Index Revisited. Review of international organizations, 14(3), 543-574.

16. Haan, J., Sturm, J. (2003). Does more democracy lead to greater economic freedom? New evidence for developing countries. European Journal of Political Economy, 19(3), 547-563.

17. Bressand (1985). Vers une Économie Mondiale à trois vitesses?’. Paris: Seghers.

18. Šimović, H. (2007). Fiscal system and fiscal relations in the European Union: political restraints and alternative approach to public finance. Retrieved from : https://hrcak.srce.hr/file/202196

19. Mimoso, M. J., Anjos, M. R. (2019). Foreign Investment and Social and Corporate Responsibility. International Journal of Innovation, Creativity and Change, 5, 131139.

20. Andrade, F. R. (2002). Concorrência Fiscal Internacional na Tributação dos Lucros das Empresas. $\quad$ Retrieved from : https://digitalisdsp.uc.pt/bitstream/10316.2/24795/1/BoletimXLV_Artigo3.pdf?ln=pt-pt

21. Mitchell, D. J. (2004). The Economics of Tax Competition: Harmonization Vs. Liberalization. Retrieved from https://static1.squarespace.com/static/56eddde762cd9413e151ac92/t/5ae9ba8970a6ad1 02dc12433/1525267090079/tax-competition.pdf

22. Lamla, M. J., Lein, S. M., Sturm, J. E. (2020). Media Reporting and Business Cycles: Empirical Evidence based on News Data. Empirical economics, 59(3), 1085-1105.

23. Stankivicius, E., Vasiliauskaité, A. (2014). Tax Burden Level Leverage on Size of the Shadow Economy, Cases of EU Countries 2003-2013. Procedia - Social and Behavioral Sciences, 156, 548-552.

24. Dombrovskis, V. (2019). Keynote speech of Vice-President Valdis Dombrovskis on challenges and impacts of implementing Basel III. Retrieved from : https://ec.europa.eu/commission/presscorner/detail/en/SPEECH_19_6269

25. Potrafke, N. (2015). The Evidence on Globalization, The World Economy, 38(3), 509552. 